Sustainable Forestry (2018) Volume 1

doi:10.24294/sf.v1i2.873

\title{
Pattern and Characterisation of Human Casualties in Sundarban by Tiger Attacks, India
}

Chandan Surabhi Das

Asst. Professor in Geography (WBES), Barasat Govt. College, West Bengal, India

\begin{abstract}
A large number of people of the fringe areas of Sundarban enter into the forests every year and encounter with the tigers simply for their livelihood. This study attempts to examine the extent and impact of human-animal conflicts in the Sundarban Reserve Forest (SRF) area in West Bengal, India. An intensive study of the data of the victims (both death and injury) between 1999 and 2014 reveals that, fishermen crab collector, honey collectors and woodcutters are generally victimized by the tiger attack. Pre monsoon period (April to June) and early winter period (Jan to March) are noted for the two-peak periods for casualties. Maximum casualty occurs between 8-10 am, and 2-4 pm. Jhilla (21.1\%), Pirkhali (19.72\%), Chandkhali (11.72\%), and Arbesi $(9.35 \%)$ are the four most vulnerable forest blocks accounting more than 60 per cent occurrence of incidences. 67.24 per cent of the tiger attack victims were residents of Gosaba followed by Hingalganja (15\%) and Basanti, $(9.76 \%)$. The vulnerability rating puts the risk of tiger attack to 0.88 for every 10,000 residents of Gosaba block followed by 0.33 at Hingalganj Block and 0.11 at Bansanti Block. The majority of the victims (68\%) were found to be males, aged between 30 and 50 years.

Keywords: Sundarban; Fringe village; Human-wildlife conflict; Depredation; Forest entrants
\end{abstract}

\section{Introduction}

In many areas of the earth humans and predating animals like lions and tigers cross path. They often share the middle and upper levels of the food pyramid and this bring them into direct conflict. Apart from competing for the same prey, the animal predators have all the adaptations required to efficiently hunt, kill and consume prey. This makes them dangerous not only to domestic livestock, but also to the humans who share their territory (Macdonald and Sillero-Zubiri, 2002). Human-wildlife conflicts are acute when the species involved is highly imperiled while its presence in an area poses a serious threat to human welfare (Saberwal et al., 1994). In one generalisation, the prey-predator ratio by weight has been estimated to $1: 111$, i.e., $10,000 \mathrm{~kg}$ of prey is required to sustain just $90 \mathrm{~kg}$ of predators (Carbon and Gittelman, 2002). Therefore, the predators require disproportionately huge amount of space than their prey. With growing population, especially in the developing countries, space has become scarce and is increasingly being competed with their animal neighbours for livestock rearing and agriculture. As a result, the relationship between people and wildlife is often antagonistic because of competition over declining resources (Weladji $\&$ Tchamba, 2003), and thus when an increasing number of people are crowded into a limited area of land, human wildlife conflicts are likely to increase. Such conflicts commonly arise when wildlife cause damage to crops, or kill livestock or game, and occasionally they involve attacks on people (Inskip \& Zimmermann 2009).Besides, carnivores readily come into conflict with humans because of their protein-rich diet, high fecundity, predatory behaviour and social organization patterns (Karnath, 2002).

Tiger is the one of the major carnivores that has a long history of conflict in densely populated countries of Asia. Mc.Dougal (1993) reported conflicts that took place between human intruders to Nepal's Royal Chitwan National Park and a man-eating tigress. In 1999, 7.8 per cent of cattle and 1.9 per cent of domesticated horses were lost to tigers in Medong county, which holds the last remnant tiger population of Tibet, China (Zhang, 2002). Johnson et al. (2004) studied a hitherto un-surveyed area at Nam Et-Pjou Louey National Protected Area of Lao PDR for status of tiger-human conflicts and found that roughly two large livestock per village were annually predated. Both Zhang (2002) 
Johnson et al. (2004) cited these losses to unavailability of adequate wild prey. In Sumatra, Indonesia, Nyhus and Tilson (2004) found that between 1978 and 1997, tigers killed some 7.7 people and at least 45.8 stock animals every year on an average. They felt that building an infrastructure for tracking the conflicts and immediately respond to them is required for management of the problem. The man-eating nature of the tigers of Bangladeshi part of Sundarban was authoritatively studied by Hendrichs (1975), who, among other factors, made the saline estuarine water responsible for this.

Sundarban has been identified as a Level I Tiger Conservation Unit (TCU), because the habitat offers the highest probability of persistence of tiger population in the long-term (Wikramanayake et al., 1999). But the growing incidences of tiger attack into the forest is a serious hazard and this often create an management issue of conserving Sundarban tiger. Records of the 18th century also mentioned the man-eating behaviour of Sundarban tiger (Chakraborty, 1986).

Despite the region is close to the industrial and commercial hub of eastern India, it remains one the least developed parts of the country and a large section of its residents has to depend on Sundarban wetlands for their livelihood. These people, because of their proximity to the mangroves and underdevelopment, are exposed to a unique set of biotic hazards - ranging from snakebites to tiger attacks - that has greatly influenced their mental make-up and socio-cultural set up. Conflict of interests between the authorities protecting the mangrove wildlife and the people utilising its resources has also become apparent in the last few decades. Incidents of tiger attack have increased over the last two decades mainly due to the increasing number of forest entrants as well as entering into the tiger's territories mainly for collection of non-timber forest products like fish, crab, honey etc.

Sundarban (both covering the areas of Bangladesh and India) is the only mangrove reserved forest in the world, which is the home of tigers and having the highest population of tigers in the world (Chowdhury et al., 2008). But, the Sundarban tigers are notorious for their man-eating traits. According to some experts, the hostility of the mangrove environment may have made them exceptionally shrewd and ferocious compared to their sub-continental counterparts (Das \& Bandyopadhyay, 2012). In the subcontinent, a man-eating tiger is usually tried to be tracked and killed. Logistic problems in Sundarban largely prevent this practice.

Based on the extent of incidences and depredation made in Sundarban, the scale of threat is very high compared to other tiger reserves of India. Our aim was then to elucidate a detailed spatial and temporal database of the hazards and identify relationships among various influential factors through statistical significance tests and to evaluate the existing methods of hazard prevention.

\section{Material Method}

\subsection{Study area}

The Sundarban is the world's largest tidal mangrove forest (Chaudhuri \& Choudhury, 1994), which is about $6 \%$ of all mangroves on earth (Khan, 2002). A UNESCO World Heritage Site, Sundarban reserve forest is a vast area covering $4262 \mathrm{~km}^{2}$ in India alone, with a larger portion in Bangladesh. Out of these reserve forests, only $2585 \mathrm{~km}^{2}$ mangrove forests and tidal water ways of the extreme south-eastern part of the Indian Sundarban have been declared as the 'Sundarban Tiger reserve'(STR), since 1973. 


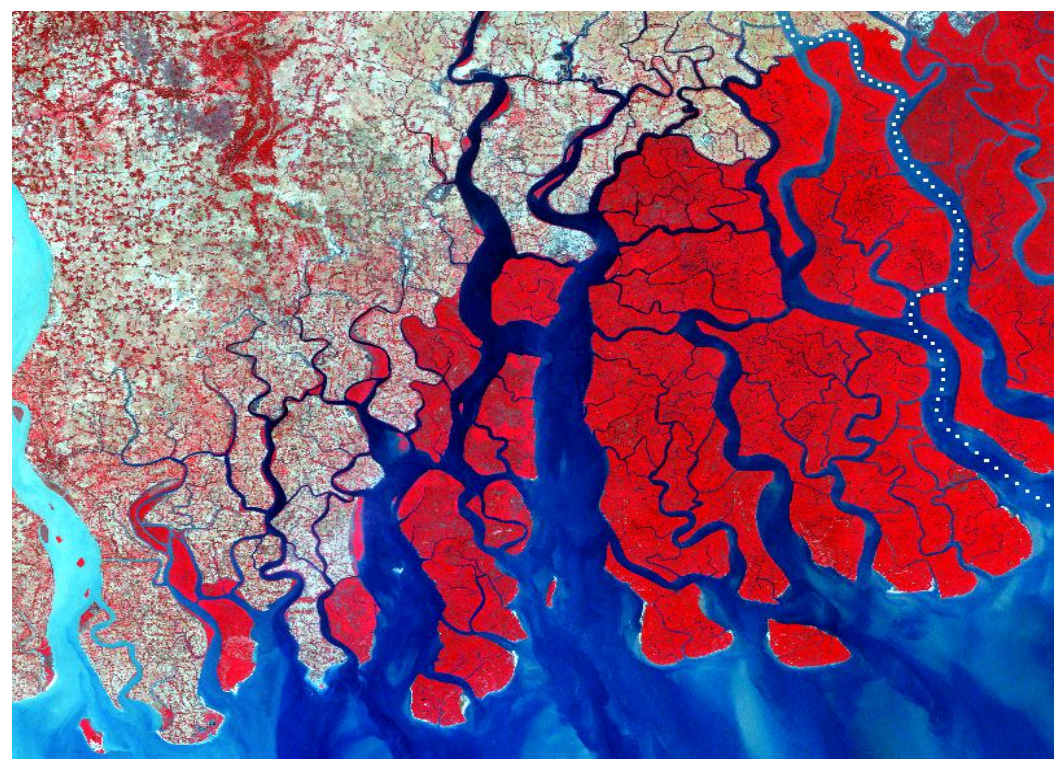

Plate 1.1: Satellite false colour composite of the study area. Pale yellow and magenta coloration denotes reclaimed and cultivated areas. The dark red patches at the lower right of the image represent the numerous islands of Sundarban mangrove wetlands. White dotted line shows West Bengal's international border with Bangladesh. Referencesto the localities are given in Figure 1.1 and 2.6. Base of the image is approximately $105 \mathrm{~km}$ across. (IRS-1C LISS-3 FCC, DoP: 22 January, 2001)

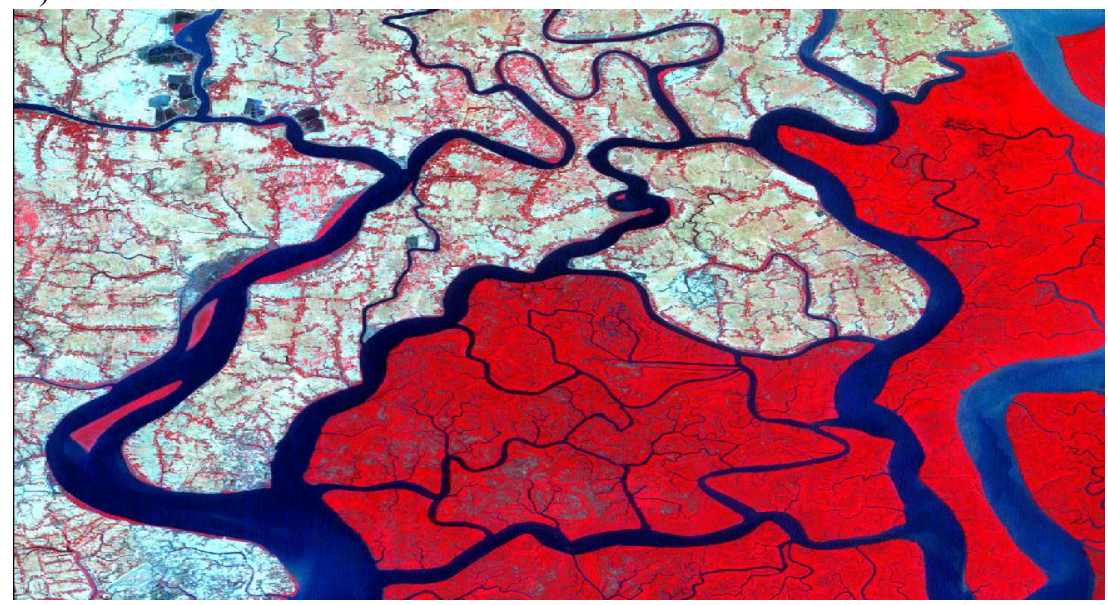

Plate 1.2: An enlargement of a portion of the above image, showing the sharp boundary between mangroves and human habitations. In location like these, it is common for the tigers to stray into inhabited areas and cause widespread depredations. Locality reference to this area is provided by Figure 4.1. Base of the image is approximately $30 \mathrm{~km}$ across. (IRS-1C LISS-3 FCC,DoP: January, 2001

The Sundarban mangrove wetlands was started to be reclaimed from 1770 (Pargiter, 1934) and since then during the next two centuries some $5364 \mathrm{~km}^{2}$ of the former tidal forests were converted to farmlands (Plate 1.1 \& 1.2). The present study is, however, confined within 5 community development blocks namely Gosaba, Basanti and Hingalganj, Patharpratima and Kultali blocks with a total area of $1644.4 \mathrm{~km}^{2}$ and a population of 1348000 (2011). These blocks were selected as located in the fringe areas of the Sundarban Reserve Forest (SRF) having population density more than 820 Persons/ sq km and a major section of people venture into the forest on a regular basis for their daily livelihood.

\subsection{Collection of data}

In the first stage, cadastral or village maps of the study area had been collected from the Directorate of Land Records and Surveys to identify the villages in the fringe areas of the study blocks may be affected by tiger straying.

In the second stage, relevant records related to the tiger-human interaction, particularly the date wise frequency of 
incidences available at forest departments had been collected from the offices of Sundarban Tiger Reserve (STR) and Sundarban Biosphere Reserve (SBR). From these data and information, 77 affected villages (55 from STR areas and 22 from South Twenty Four Parganas forest division) were identified where at least one forest user had been attacked during venture in the of forest.

In the third stage, to identify causes, consequence nature of conflict as well as to prepare a spatio-temporal database, a door-to-door household survey was conducted during a period of May 2012 to April 2014 to collect the primary data of the hazards under study. The data on tiger attack in Sundarban were collected on the locality (forest block, river creek), date, time, occupation of victim, sex of victim, distance of nearest forest beat office, result of the conflict (death or injury), depredations made and status of the entrant (legal user or illegal user).

Two criteria were used in the selection of the households, first, with at least one member directly involved in felling of trees, collection of fuel wood, fishing, honey collection or crab collection activities as primary occupation second, with people willing to share information openly. This was crucial as most of them were illegal forest entrants and therefore they tend to be extremely suspicious of outsiders to express their views.

In the fourth stage, ten Focus Group Discussions (FGD) comprising 10-12 persons (injured victims of tiger attacks, villagers head, panchayet member, forest guard, woodcutters, honey collectors, TPS/crab collectors and EDC or FPC members) was conducted to elicit their perception about the human-tiger conflicts and different aspects of alternate livelihood measures.

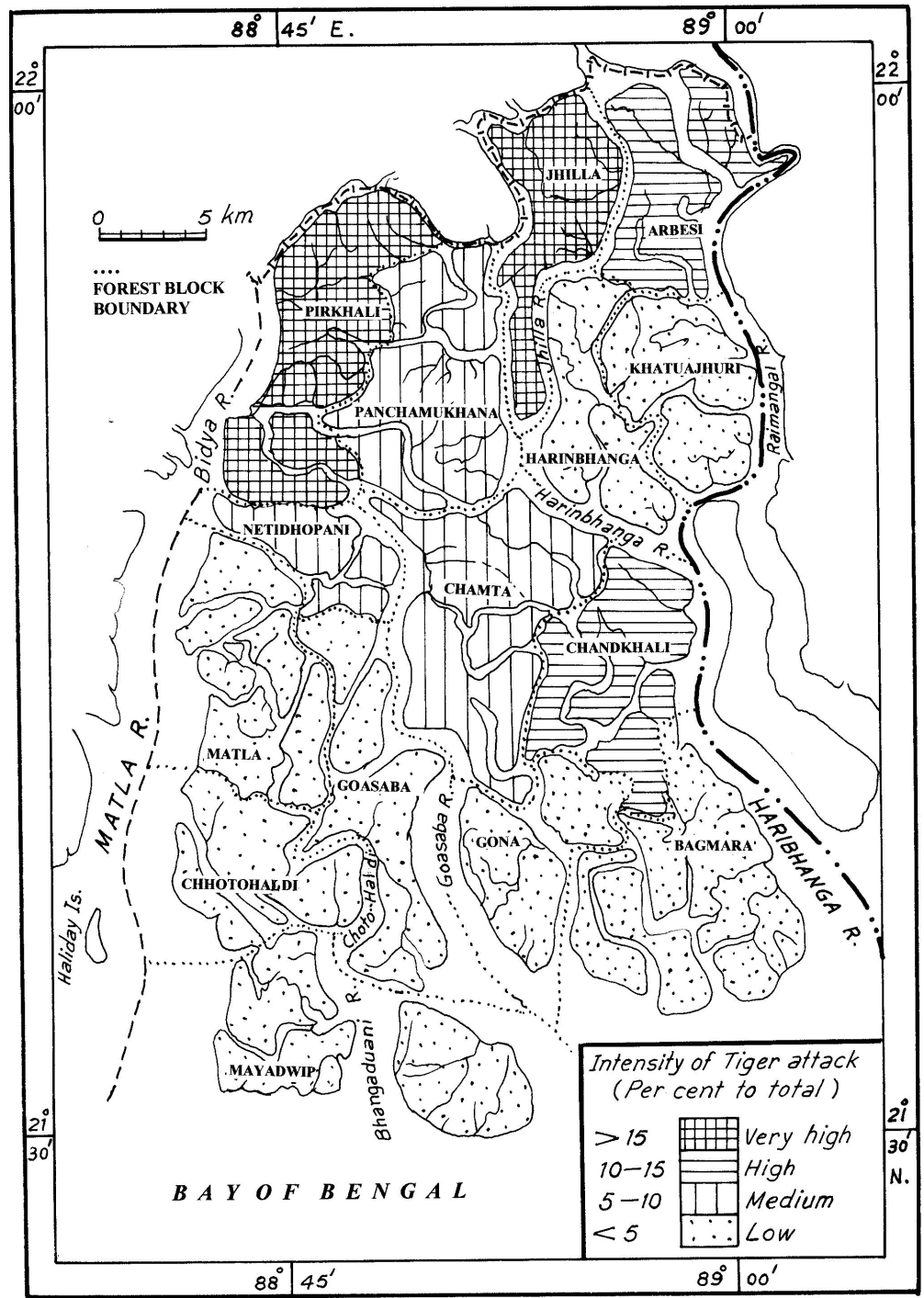

Figure 1; Distribution of tiger attacks by forest blocks where the incidents took place: 1985-2000. $\mathrm{n}=492$. The area constitutes the Sundarban Tiger Reserve. (Source: Village survey, STR, Death Registry Office and RCHP). 


\section{Results}

1155 respondents comprising at least 10 respondents (no two respondents from same household) of each village were interviewed and questionnaires were filled up accordingly. Details from respondents are summarized in the table below.

\begin{tabular}{|c|c|c|c|c|c|c|c|c|c|}
\hline \multirow{2}{*}{$\begin{array}{l}\text { No. of } \\
\text { respondents }\end{array}$} & \multirow{2}{*}{$\begin{array}{l}\text { Mean } \\
\text { age }\end{array}$} & \multicolumn{2}{|l|}{ Sex } & \multicolumn{2}{|c|}{ Education status } & \multirow{2}{*}{$\begin{array}{l}\text { No. of family } \\
\text { owing } \\
\text { domestic } \\
\text { animals }\end{array}$} & \multirow{2}{*}{$\begin{array}{l}\text { Total no. } \\
\text { of cattle } \\
\text { number }\end{array}$} & \multirow{2}{*}{$\begin{array}{l}\text { People } \\
\text { having } \\
\text { agricultural } \\
\text { land }\end{array}$} & \multirow{2}{*}{$\begin{array}{l}\text { Land less } \\
\text { People } \\
\text { totally } \\
\text { dependant } \\
\text { on forest } \\
\end{array}$} \\
\hline & & M & $\mathrm{F}$ & Literate & $\begin{array}{l}\text { Non- } \\
\text { literate }\end{array}$ & & & & \\
\hline 1552 & 47.7 & 960 & 592 & 876 & 676 & 1123 & 7861 & 1004 & 425 \\
\hline
\end{tabular}

Table 1. Characteristics of respondents

During the period between 1999 and 2014 a total 437 incidents of human tiger conflict occurred in Sundarban forest, an average of 29 incidents per year. However, the average number of incidents increased from 22 per year during 1999-2002 to 33 per year during 2003-2014.

In the Sundarban Tiger Reserve area, there are 15 forest blocks comprising about 258,489.04 ha of forest and water bodies. These are uninhabited and different from the community development blocks of the region. The tiger victim data of the last 15 years denoted that Jhilla (21.1\%), followed by Pirkhali (19.72\%), Chandkhali (11.72\%), and Arbesi $(9.35 \%)$ were the four most vulnerable blocks, accounting for more than 60 per cent of the persons attacked and killed by tigers (Fig.). All these forest blocks, except Chandkhali, border the fringe villages of Gosaba and Hingalganja blocks, from where a large number of people regularly venture into the forest for their livelihood. Intensity of tiger attacks is comparatively low in the forest blocks of Gona, Bagmara, Mayadwip, Gosaba and Matla because of their location far from the inhabited areas (Figure 1).

Some 67.24 per cent of the tiger attack victims were residents of Gosaba block. Hingalganja (17.12\%) was the second most vulnerable block followed by Basanti, (10.34\%), Pathar Pratima (2.91\%), Kultali (2.33\%). On the other hand, Satjalia, Jamespur, Dayapur, Lahiripur and Rajat jubilee villages of Gosaba block and Samsernagar, Chargheri, and Hingalganj villages of Hingalganj block constitute the most affected villages (Table 2.).

\begin{tabular}{|l|l|l|l|l|l|l|}
\hline Block & Gosaba & Hingalganja & Basanti & $\begin{array}{l}\text { Pathar } \\
\text { Pratima }\end{array}$ & Kultali & Total \\
\hline Number of incidents & 289 & 74 & 45 & 13 & 10 & 431 \\
\hline Percentage of all incidents (n=431) & 67.24 & 17.18 & 10.34 & 2.91 & 2.33 & 100 \\
\hline Yearly average of incidents & 19.26 & 4.93 & 3.00 & 0.87 & 0.67 & 28.73 \\
\hline $\begin{array}{l}\text { Vulnerability per 10,000 } \\
\text { population }\end{array}$ & 0.88 & 0.31 & 0.11 & 0.03 & 0.04 & -- \\
\hline
\end{tabular}

Table 2. Distribution of residents of victims of tiger attacks by blocks: 1999-2014

The vulnerability rating puts the risk of tiger attack to 0.88 for every 10,000 residents of Gosaba block. Hingalganja, at 0.31 for 10000 persons faces a noticeably lower risk. The vulnerability rating increases by a magnitude when the villages, the residents of which were most affected by tiger attacks are considered. In Dayapur, Samsernagar and Jamespur villages close to four persons per 10,000 villagers are susceptible to tiger attacks every year (Table 3). This rate is very high on any count and not incomparable to epidemic situation. 


\begin{tabular}{|c|c|c|c|c|c|c|c|c|c|c|c|}
\hline 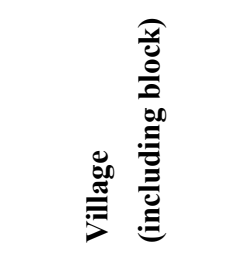 & 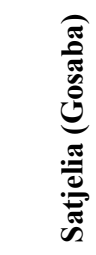 & 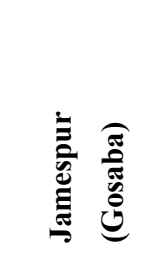 & 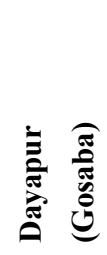 & 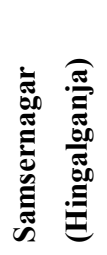 & 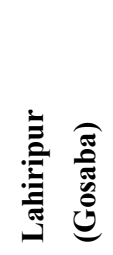 & 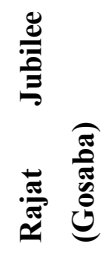 & 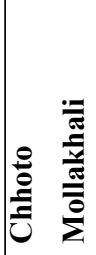 & 氕 & 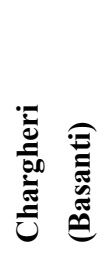 & 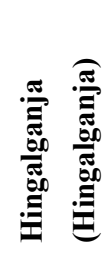 & 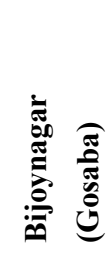 \\
\hline No of victims & 43 & 32 & 31 & 23 & 21 & 20 & 20 & & 17 & 15 & 12 \\
\hline $\begin{array}{l}\text { Percentage of } \\
\text { victims }(n=234)\end{array}$ & 18.37 & 13.67 & 13.25 & 9.83 & 8.97 & 8.54 & 8.54 & & 7.26 & 6.41 & 5.13 \\
\hline $\begin{array}{l}\text { Yearly average of } \\
\text { incidents }\end{array}$ & 2.86 & 2.13 & 2.07 & 1.53 & 1.39 & 1.33 & 1.33 & & 1.13 & 1.00 & 0.80 \\
\hline $\begin{array}{l}\text { Vulnerability per } \\
10,000 \text { population }\end{array}$ & 2.81 & 3.73 & 3.81 & 3.77 & 2.13 & 2.80 & 1.36 & & 1.81 & 1.20 & 1.79 \\
\hline
\end{tabular}

Table 3. Villages, the residents of which were affected most by tiger attacks: 1999-2014

Source: Village survey, STR, Death Registry Office and RCHP

Tiger attacks on humans are characteristically distributed throughout the year. Pre monsoon period (April to June: 29.54\%) and early winter period (Jan to March: 25.51\%) are noted for the two-peak periods for casualties. However, the attacks peak in April, during which 20.33 per cent attacks took place. October, on the other hand, is the month recording least number of attacks at 5.48 percent.

On the other hand, 29.01 per cent of the tiger attacks took place during $8-11$ a.m. and 27.69 per cent during $2-5$ p.m. As high as 76.35 per cent of the killings occurred between 8 a.m. to 5 p.m. Attacks are more likely in daytime than at nights. The four categories of people who are most liable to get attacked by tigers are the fishermen, crab collectors, honey collectors, woodcutters and forest departmental staff. 232 fishermen (63.04\%) were killed by tigers as against 64 $(17.39 \%)$ crab collector, $49(13.31 \%)$ honey-collectors, $20(5.43 \%)$ woodcutters and $3(0.82 \%)$ staff of the Forest Department (Table 4). Although tiger attack incidents were observed in all age groups, the majority of the victims (68\%) were found to be males, aged between 30 and 50 years. The female-male ratio of the persons killed by tiger's stands at 1:26.

\begin{tabular}{|c|c|c|c|c|c|c|c|c|c|c|c|c|}
\hline \multirow{2}{*}{$\begin{array}{l}\text { Profession } \\
\\
\text { Result of } \\
\text { Attack }\end{array}$} & \multicolumn{2}{|c|}{$\begin{array}{l}\text { Fisherman } \\
\text { (Including } \\
\text { tiger prawn } \\
\text { collector) }\end{array}$} & \multicolumn{2}{|c|}{ Crab collector } & \multicolumn{2}{|c|}{$\begin{array}{l}\text { Honey-collecto } \\
\text { r }\end{array}$} & \multicolumn{2}{|c|}{ Woodcutter } & \multicolumn{2}{|c|}{$\begin{array}{lr}\text { Forest Dept. } \\
\text { Staff (both } \\
\text { casual and } \\
\text { permanent) } \\
\end{array}$} & \multicolumn{2}{|l|}{ Total } \\
\hline & Death & Injury & Death & Injury & Death & Injury & Death & Injury & Death & Injury & Death & Injury \\
\hline $\begin{array}{l}\text { Number of } \\
\text { victims }\end{array}$ & 232 & 41 & 64 & 10 & 49 & 8 & 20 & 4 & 3 & 0 & 368 & 63 \\
\hline $\begin{array}{l}\text { Percentage } \\
\text { of victims }\end{array}$ & 63.04 & 65.08 & 17.39 & 15.87 & 13.31 & 12.70 & 5.43 & 6.35 & 0.82 & 0 & 100 & 100 \\
\hline
\end{tabular}

Table 4. Distribution of victim of fatal tiger attacks by profession: 1999-2014

Source: Village survey, STR, Death Registry Office and RCHP

Obviously, this group of the population remains most active in the forests. It is also connoted by the study that persons below 20 years $(3.26 \%)$ and above 60 years of age $(1.63 \%)$ are least affected, as they are not suitable for vigorous activities like honey collection, woodcutting or fishing (Table 5). 


\begin{tabular}{|l|l|l|l|l|l|l|}
\hline \multirow{2}{*}{$\begin{array}{l}\text { Age groups } \\
\text { (Years) }\end{array}$} & \multicolumn{2}{|l|}{ Male } & Female & \multicolumn{2}{l|}{ Total } \\
\cline { 2 - 7 } & Number & Per cent & Number & Per cent & Number & Per cent \\
\hline$<20$ & 9 & 2.58 & 3 & 15.79 & 12 & 3.26 \\
\hline $20-30$ & 45 & 12.89 & 5 & 26.31 & 50 & 13.59 \\
\hline $30-40$ & 119 & 34.09 & 1 & 5.26 & 120 & 32.61 \\
\hline $40-50$ & 123 & 35.24 & 3 & 15.79 & 126 & 34.24 \\
\hline $50-60$ & 47 & 13.46 & 7 & 36.84 & 54 & 14.67 \\
\hline$>60$ & 6 & 1.72 & 0 & 0 & 6 & 1.63 \\
\hline Total & 349 & 100.00 & 19 & 100.00 & 368 & 100.00 \\
\hline
\end{tabular}

Table 5. Age structure of the victims

\section{Discussion}

Source: Village survey, STR, Death Registry Office and RCHP

The available data indicate that intensity of tiger attacks between 1999 and 2014 fluctuated like a sine curve (Figure 2). Between 1995 and 1999, the incidents decreased with the introduction of measures like prohibition of entering into hental (Phoenix paludosa) forests that are frequented by tigers and establishment of electrified dummies and rear-face masks. Both electrified dummies and masks were discontinued from 1989 and the frequency of attacks ascended from an all-time low of 10 in 1989 to 49 in 1993. A sharp decrease in frequency was again recorded from 1994 to 1996 due to reintroduction of the measures. In recent times, an upward trend is observed due probably to lack of monitoring of the protective measures as well as an increase in the illegal entry into the forests. It is also revealed by the data that an overwhelming majority -87 per cent—of the attacks were fatal. During the 16 years under review, only 13 per cent of the tiger attack victims could escape with their lives.

Tiger attacks on humans are characteristically distributed throughout the year (Das, 2005, 2011, 2015). As the data of the period 1985-2000 indicate, the attacks peak in pre-monsoon, especially in April, during which 20.33 per cent of the 492 attacks took place. October, on the other hand, is the month recording least number of attacks at 5.48 per cent. This pattern seems to corroborate the observations made by Hendrichs (1975), who related increase in salinity in the estuarine waters of Sundarban during April with increase in the frequency of attacks. April is also the peak honey collection season when both the frequency and number of moulis are maximum and the converse is true from October to December. Although November-January is the main fishing season in Sundarban, some fishing activity is also carried out during March-June. As will be seen below, 80 per cent of all tiger victims were fishermen and only 14 per cent were moulis.

Systematic recording of tiger attack incidents, however, was started only after the Project Tiger came into being in 1973. It must be noted that because the STR records only attacks on persons who hold valid permit for entering the forests, probably a large number of attacks go undocumented every year (Das, 2009).

During the months of April and May, the STR harbours numerous hives of rock bees (Apis dorsata). In an average year, nearly 700 honey-collectors, called moulis, enter the forests with permits from STR authorities (Table 5.3). On yearly average, 50 metric tones of honey and 3,000 kg of beeswax are collected during these two months ((Das \& Bandyopadhyay, 2012). The woodcutters, called bāulis, and fishermen are permitted to enter the forests throughout the year, in restricted numbers, within specified areas. For example, a typical Sundarban fisherman would go into the forests at least 20 times in any given year. Chakrabarti, in 1986 estimated that some 30,000 entries-both legal and illegal - are made to the buffer areas of STR. It, however, seems to be an underestimate at present and the figure should be at least 50,000 entries per year (Das \& Bandyopadhyay, 2012).

As high as 76.35 per cent of the killings occurred between 8 a.m. to 5 p.m during which most of the human activity takes place within the forests. Those killed or injured during rest of the day were mainly attacked in their boats at the time of return. This agrees with Hendrichs' (1975) observation in Bangladesh, that 38 per cent of killings took 
place during 8-10 a.m.; 29 per cent during 2-4 p.m.

The data revealed that the fishermen are the worst sufferers from tiger attacks followed by honey-collectors, woodcutters and Forest Department staff. During the last 16 years, 341 fishermen $(79.48 \%$ of total) were killed by tigers as against $59(13.76 \%)$ honey-collectors, $22(5.12 \%)$ woodcutters and $6(1.4 \%)$ staffs of the Forest Department (Table ).

Among the various types of preventive measures taken so far to reduce tiger attacks, facemasks and electrified dummies were proven the most effective. The masks won large popularity owing to their low cost. The effectiveness of the recently introduced fibreglass headgear is not yet clear because no one wearing this gear has been attacked by tigers (Das \& Bandyopadhyay, 2012). Any reduction in man-eating behaviour of tigers was not noticed in vicinity of fresh water ponds. Therefore, effectiveness of this measure in controlling tiger attacks is doubtful.

The changes in the pattern of tiger attack over the last 25 years indicate a close relationship between implementation of the measures and number of victims. The effectively of the implemented measures, however, got reduced after a few years probably due to lack of monitoring and inaccuracy of implementation (Das, 2011).

On a yearly average, the minimum number of attacks took place during the periods 1994-1997 (12.3 per year) and 1987-1989 (15.3 per year), when the measures were implemented and monitored properly. On the other hand, the figures soared in 1975-1979 (48 per year) and 1990-1993 (45.3 per year), during which the preventive measures were either discontinued or continued partially with poor supervision (Figure 2).

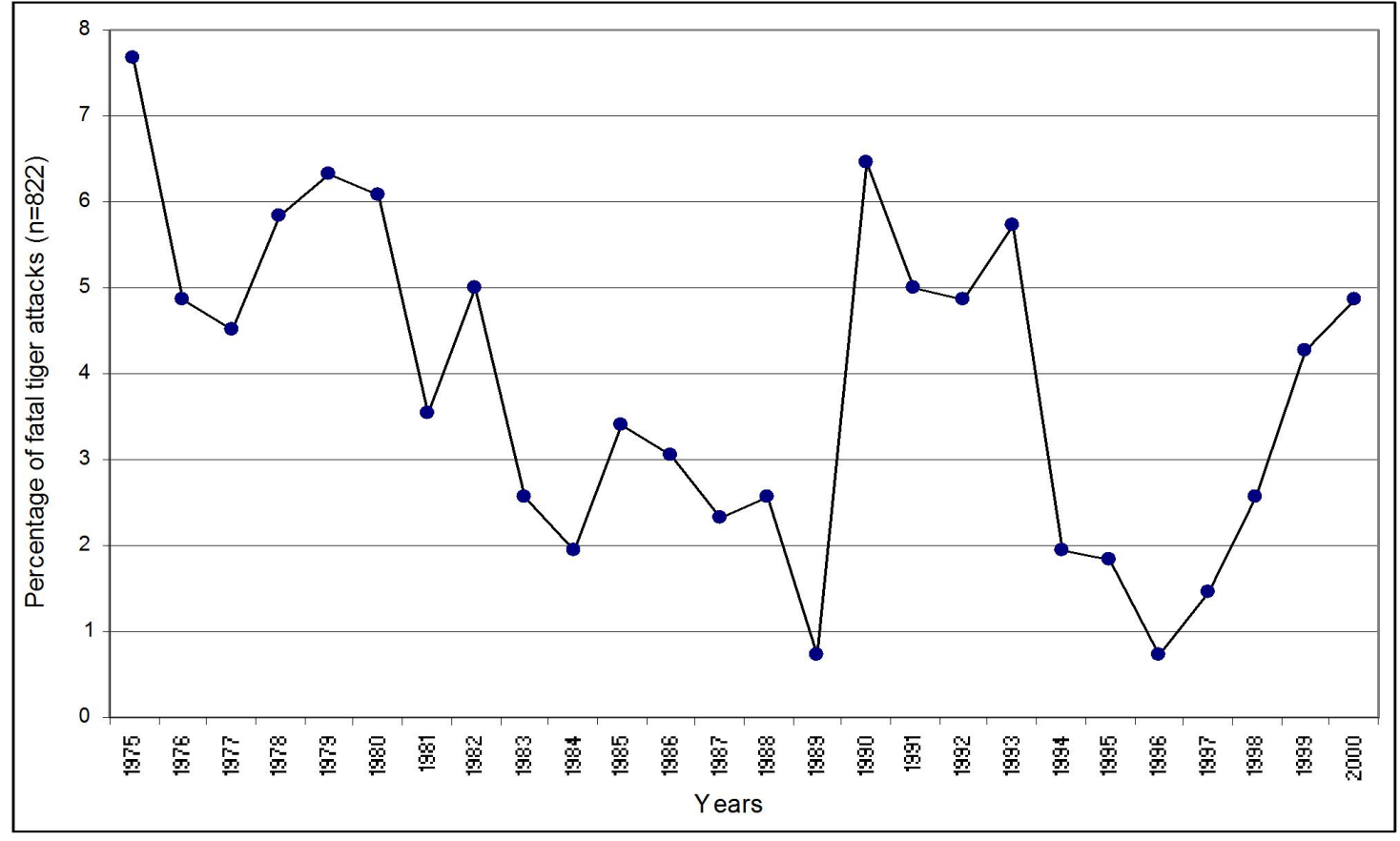

\section{Conclusion}

Figure 2; Temporal distribution of fatal tiger attacks.

The large number of tiger attacks can largely be ascribed to unauthorized entry into the forests. Keeping strict vigil in Sundarban, which has a vast and intricate network of creeks and a long international boundary with Bangladesh, is not an easy task. It has been made all the more difficult by poor infrastructural facilities and staff strength of the Forest Department (Das \& Bandyopadhyay, 2012). Providing adequate equipment like fast-moving speedboats and manpower to the Forest Department would go a long way in preventing illegal activities inside the forests and thereby reducing chances of assault by tigers.

This survey revealed that at present the Forest Department owns 15 mechanised launches that operate in different parts of Sundarban (Das, 2005). In addition, the Department also takes a number of vessels on hire from private operators every year. All these boats are at least 10 years old and cannot do more than $20 \mathrm{~km} \mathrm{hr}^{-1}$. This is clearly inadequate for patrolling a large area in a short period of time. Apart from the equipment, it was found that the staffs 
manning the interior posts of the Forest Department have no access to updated maps. In a rapidly changing region, they use old survey maps of the forest ranges dating back to 1920s. Many creeks shown in these maps have decayed beyond recognition and new ones have opened up.

It is also suggested that some of the measures that helped to bring down the frequency of tiger attacks should be reintroduced with proper maintenance of the equipment (Das, 2012). However, increased co-operation from the people, living in the fringe areas of the forests, in conservation of the tiger habitat has been achieved in the recent decades through constant motivation and awareness building programmes. If even a section of the people who venture into the forests can be persuaded for not using the forests for their livelihood, the root cause of tiger attacks can be eradicated to some extent. However, to do this, alternative employment opportunities should be given to the fishing, woodcutting and honey-collecting communities to a large extends.

\section{Acknowledgement}

I would like to thank Dr. Sunando Bandyopadhyay, Professor of Geography, University of Calcutta for his guidance and help in preparation of this paper. I am also grateful to the authorities of forest department, Government of West Bengal specially Dr. Pranobes Sanyal, Ex-Additional Principal Chief Conservator of forest, for necessary help and valuables suggestions.

\section{Reference}

1. Carbone, C, Gittelman JL. 2002. A common rule for the scaling of carnivore density. Science 295: 2273-2276.

2. Carnivores readily come into conflict with humans because of their protein-rich diet, high fecundity, predatory behaviour and social organization patterns.

3. Chakrabarty K.1986. Tiger (Panthera tigris tigris) in the mangrove forests of Sundarbans e an ecological study. Tigerpaper 13 (2), 8-11.

4. Chaudhuri A, Choudhury A. 1994. Mangroves of the Sundarban. Volume : India. IUCN, Gland, Switzerland.

5. Das CS. 2005. Tiger Straying Hazards in Sundarban, West Bengal. Geographical Review of India 67(1): 80-87.

6. Das CS. 2009. Spatio-temporal study of the hazards induced by tiger attack in Sundarban, West Bengal. Indian Journal of landscape systems and Ecological Studies 32 (1): 330-338.

7. Das CS. 2011. Characterization and prevention of large carnivore-human conflict in Sundarban: a study of tiger straying incidents. In Sundarbans- issues \& threats, ed. K. Naskar, A. Bhattacharya, 16-27. Central Inland Fisheries Research Institute (ICAR), Kolkata.

8. Das CS. 2015. Causes, Consequences and Cost-Benefit Analysis of the Conflicts Caused by Tiger Straying Incidents in Sundarban, India. Proceedings of the Zoological Society 68 (2): 120-130.

9. Das CS, Bandyopadhyay.S. 2012. Sharing Space: Human-Animal Conflicts in Indian Sundarban. Progressive Publishers, Kolkata

10. Hendricks H. 1975. The status of the tiger Pantheratigris (Linne 1758) in the Sundarban Mangrove forest (Bay of Bengal). Saingetierkundliche Mitteilungen 23 (3):161-199.

11. Inskip C,Zimmermann A. 2009. Human-felid conflict: a review of patterns and priorities worldwide. Oryx 43, 18-34.

12. Johnson A, Vongkhamheng C, Hedemark M,et al. 2004. The status of tiger, prey and human-tiger conflict in the Nam Et - Phou Louey National Protected Area. Wildlife Conservation Society, Vientiane.

13. Karanth KU. 2002. Human-carnivore conflict: strategies for mitigation and prevention, 2002 State of Carnivore Science, Society for Conservation Biology. Bronx, New York.

14. Khan MMH. 2002. The Sundarban. In Wilderness: Earth's Last Wild Places (eds R.A. Mittermeier, C. Goettsch Mittermeier, P. Robles Gil \& J. Pilgrim), pp. 280-289. Conservation International, Arlington, USA.

15. Macdonald DW,C Sillero-Zubiri. 2002. Large carnivores and conflict: Lion conservation in context. In Lion conservation research Workshop 2: modelling conflict, ed. AJ Loveridge, T Lynam, DW Macdonald, 1-8. Wildlife Conservation Research Unit, Oxford University.

16. McDougal C. 1987. The Man-eating tiger in geographical and historical perspective. In Tigers of the World: The Biology, Biopolitics, Management and Conservation of an Endangered Species, ed. R.L. Tilson and R.S. Seal, 435-488. Park Ridge, New Jersey, Noyes Publications.

17. Nyhus, PJ,Tilson R. 2004. Characterizing human-tiger conflict in Sumatra, Indonesia: implications for conservation. Oryx 38: 68-74.

18. Pargiter FE. 1934. A Revenue History of the Sundarbans from 1765 to 1870. Bengal Govt. Press, Calcutta.

19. Saberwal VK,Gibbs JP,Chellam R,et al.1994. Lion-human conflict in the Gir forest, India. Conservation 
Biology 8: 501-507.

20. Weladji RB,Tchamba MN. 2003. Conflict between people and protected areas within the Bénoué Wildlife Conservation Area, North Cameroon. Oryx, 37, 72-77.

21. Wikramanayake ED, Dinerstein E,Robinson G, et al.1999. Where can tigers live in the future? A framework for identifying high-priority areas for the conservation of tigers in the wild, pp. 255-272. In: Seidensticker, J., S.

Christie \& P. Jackson (eds.). Riding the Tiger: Tiger Conservation in Human-dominated Landscapes. Cambridge University Press, Cambridge, UK.

22. Zhang E, George B,Schaller Lü Zhi,et al.2002. Tiger Predation On Livestock in Gedang, Wildlife Conservation Society, Tibet, China. 